\title{
Reproductive biology of female Nile tilapia Oreochromis niloticus (Linnaeus) reared in monoculture and polyculture with African sharptooth catfish Clarias gariepinus (Burchell)
}

\author{
A P Shoko', S M Limbu², H D J Mrosso ${ }^{2,3}$ and Y D Mgaya ${ }^{2 *}$
}

\begin{abstract}
This study was conducted to assess the reproductive biology and early breeding behaviour of female Oreochromis niloticus reared in monoculture and polyculture with Clarias gariepinus in earthen ponds for 8 months. Results revealed no significant difference in length at first maturity $\left(L_{50}\right)$ between females reared in monoculture and polyculture systems. Similarly, no significant differences were detected in absolute fecundity, relative fecundity, gonadosomatic index and condition factor between the two culture systems. The absolute fecundity was more strongly correlated with total length and body weight than with ovary weight. The study concluded that early breeding of O. niloticus in captivity is not affected by the culture systems used. Therefore, O. niloticus production in either system can be improved only through proper pond management techniques.
\end{abstract}

Keywords: Early maturation, Prolific breeding, Tilapia culture systems, Grow-out ponds, Fecundity, Ovary weight

\section{Background}

Nile tilapia Oreochromis niloticus (Linnaeus, 1757) is a worldwide important species in aquaculture because of its fast growth, firm and tasty flesh, resistance against harsh conditions and ease production of fingerlings under captivity (Fryer and Iles 1972; Yi et al. 1996; de Graaf et al. 1999; Gómez-Márquez et al. 2003). However, early maturation and prolific breeding of $O$. niloticus in culture systems, especially earthen ponds is a major problem in tilapia farming (Bardach et al. 1972; McGinty 1985; Suresh and Bhujel 2012). The large numbers of fingerlings produced through reproduction during growout consume the feeds and dissolved oxygen intended for the stocked tilapia (de Graaf et al. 1996). Consequently, the growth rate decreases with fewer marketable-size fish. In the wild, $O$. niloticus starts to reproduce at a total length of 20-30 cm (150-250 g) (Lowe-McConnell

\footnotetext{
*Correspondence: yunusmgaya@gmail.com

${ }^{2}$ Department of Aquatic Sciences and Fisheries, University of Dar es

Salaam, P. O. Box 35064, Dar es Salaam, Tanzania

Full list of author information is available at the end of the article
}

1958; Gwahaba 1973). However, under captivity O. niloticus reaches sexual maturity at a relatively smaller size of 8-13 cm (Siraj et al. 1983; de Silva and Radampola 1990; Suresh and Bhujel 2012).

Methods adopted to control overpopulation in farmed tilapias have been reviewed by Guerrero (1982) and Mair and Little (1991). These methods include monosex culture through manual sexing and hormonal sex reversal, cage culture, high stocking density, sterilization, intermittent (selective) harvesting and the use of slow maturing tilapia species or strains. However, these methods have their limitations. For example, the use of reproductive inhibitors (sterilization) such as irradiation or chemosterilants are expensive and require hatchery facilities and skilled manpower. The intervention of hormones is also expensive and sometimes difficult to obtain (Jegede 2010). On the other hand, the use of predator-control method such as African sharptooth catfish Clarias gariepinus (Burchell, 1822) through polyculture has been considered a safe biological method for controlling unwanted reproduced fingerlings in mixed-sex tilapia population in ponds without affecting the big size (c) 2015 Shoko et al. This article is distributed under the terms of the Creative Commons Attribution 4.0 International License (http://creativecommons.org/licenses/by/4.0/), which permits unrestricted use, distribution, and reproduction in any medium, provided you give appropriate credit to the original author(s) and the source, provide a link to the Creative Commons license, and indicate if changes were made. 
tilapia (Abdel-Tawwab 2005). The reproductive biology of female $O$. niloticus reared in monoculture system has been investigated by de Graaf et al. (1999). However, limited attempts have been made to assess the reproductive biology of female $O$. niloticus in polyculture system. This assessment is useful in ensuring the well-being of the cultured fish (Moreau et al. 1986), enabling protection of new recruits (King and Udo 1998).

The objective of the present study was to determine the reproductive biology of female O. niloticus with an emphasis on its early breeding behaviour under monoculture and polyculture pond systems. In order to address this objective, it was hypothesised that $O$. niloticus reared in monoculture system attains sexual maturity earlier and at a smaller size than those reared under polyculture system.

\section{Methods}

\section{Ethical statement}

This study was not evaluated by an Animal Ethics Committee because there was no such committee in Tanzania during the course of the study. Nevertheless, the research methods used for fish sampling followed internationally recognised guidelines for ethical use of animals (for example, Håstein 2004; Grigorakis 2010). The fish used for determination of maturity stages were sacrificed by hypothermia through immersing them in an ice-slurry to avoid causing stress and pain before death (Sneddon 2006). By using ice water, it was possible to calm down the fish for several hours until osmoregulatory problems and exhaustion occur. It has been demonstrated that pre-chilling prior to slaughter is a minor stressor (Sneddon 2012).

\section{Study site}

The study was conducted in the Lake Victoria basin, Tanzania at Kimusi village, Tarime District, of Mara Region (Figure 1). Kimusi village is located between latitudes $1^{\circ} 10^{\prime \prime}$ and $1^{\circ} 36^{\prime \prime}$ South of the Equator and longitudes $34^{\circ} 08^{\prime \prime}-35^{\circ} 01^{\prime \prime}$ East of Greenwich Meridian at an altitude ranging from 1,500 to $1,800 \mathrm{~m}$ above sea level. The mean annual rainfall in this area ranges from 1,200 to $1,500 \mathrm{~mm}$ while the range of mean annual temperature is $18-26^{\circ} \mathrm{C}$. This village has deep, well-drained, red or brown soils on the gentle hillsides. In the valleys the area become shallow and stony on the steeper slopes and dark-grey or brown clays with obstructed drainage. The area is characterized by the fertile soils which make it important in agricultural production (URT 1998).

\section{Experimental procedures}

The experiment was conducted in six earthen fish ponds of $150 \mathrm{~m}^{2}$ with a mean depth of $1.25 \mathrm{~m}$ each. The ponds received water from the source of Mori River that drains to Lake Victoria. Three ponds were stocked with $O$. niloticus and C. gariepinus in polyculture while the other three ponds were stocked with $O$. niloticus in monoculture. A stocking ratio of 1:3 for C. gariepinus and O. niloticus was adopted for polyculture treatment. Both culture systems were stocked with fingerlings of mean $( \pm \mathrm{SE})$ initial weights of $5.01 \pm 0.01 \mathrm{~g}$ at a stocking density of 9 fish $\mathrm{m}^{-2}$. For polyculture ponds, stocking of similar initial weights of $C$. gariepinus was intentionally delayed for 30 days to allow $O$. niloticus to grow to a size $(12.26 \pm 9.49 \mathrm{~g})$ that $C$. gariepinus were unable to prey on (Shoko et al. 2014a).

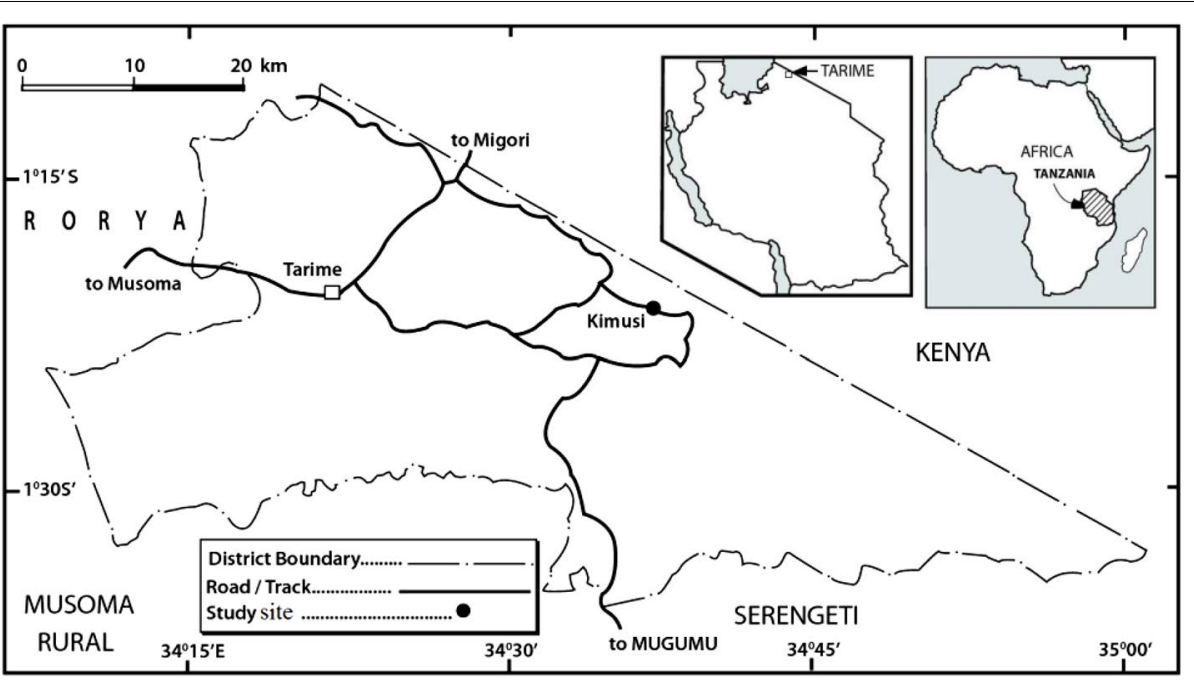

Figure 1 Map of Tarime District, Tanzania showing study site (source: University of Dar es Salaam Cartographic Unit). 
In order to regulate pond water $\mathrm{pH}$ and water chemistry in general, before fish stocking, the ponds were drained and limed with dolomite at a rate of $0.25 \mathrm{~kg} \mathrm{~m}^{-2}$ (Engle and Neira 2005). Fish were fed on $297.50 \mathrm{~g} \mathrm{~kg}^{-1}$ crude protein diet made using locally available cotton seed cake $683.40 \mathrm{~g} \mathrm{~kg}^{-1}$ and maize bran $316.60 \mathrm{~g} \mathrm{~kg}^{-1}$ of dry feed (Table 1) adopted from Shoko et al. (2014b). Food was supplied at a constant daily feeding rate of $5 \%$ per body weight for O. niloticus or for the combined body weights of $O$. niloticus and $C$. gariepinus in the case of polyculture. This feeding rate was done so intentionally to reflect the actual practice by small scale rural fish farmers in the study area. The ration was apportioned into two and fed twice per day in the morning between 09:00 and 10:00 $\mathrm{h}$ and evening between 15:00 and 16:00 h. Fish sampling which was done on a monthly basis started during the third month of the experiment to allow for gonadal development. The duration of the study was 8 months.

\section{Determination of gonad maturity stages}

Ten $O$. niloticus females were collected using a small seine net $(12.7 \mathrm{~mm})$ and were sacrificed by immersing them in an ice-slurry before being dissected for reproductive studies. The gonads were carefully excised, trimmed to remove extraneous fat and connective tissue in order to determine the maturity stage of the gonads.

Table 1 Formulation and proximate composition (dry matter basis) of feed used in the study

\begin{tabular}{lc}
\hline Ingredients & Composition $\left(\mathbf{g ~ k g}^{-\mathbf{1}}\right) \mathbf{d r y}$ feed \\
\hline Cotton seed cake meal & 683.40 \\
Maize bran meal & 316.60 \\
Total & 1000.00 \\
Proximate composition offeed & \\
Dry matter & 924.70 \\
Crude protein & 297.50 \\
Crude fibre & 136.70 \\
Crude fat & 109.60 \\
Ash & 68.10 \\
Carbohydrate & 388.10 \\
\hline
\end{tabular}

The maturity stages of the fish gonads were determined through visual inspection of the appearance, size and texture, according to the scale adopted from Mous et al. (1995) as shown in Table 2.

\section{Determination of size at first maturity $\left(\mathrm{L}_{50}\right)$}

The $L_{50}$ is the length of the onset of sexual maturity, i.e. stage IV (Marriot et al. 1997) at which $50 \%$ of females have reached sexual maturity. For this purpose, females were grouped into immature (stages I-III) that are not ready to spawn in the nearest breeding cycle and mature females (stages IV and V) that are going to spawn in the next spawning cycle. The $\mathrm{L}_{50}$ was estimated using the following equation (Silberberg et al. 2001):

$$
P=\frac{1}{1+e^{-a(L-b)}}
$$

where $P=$ proportion of mature fish at a specific length class (measured as total length); $a$ and $b$ are model parameters to be estimated; $L=$ total length.

\section{Determination of condition factor}

The condition factor $(K)$ is used to compare the condition ('fatness') and the wellbeing of a fish and according to Bagenal (1978) heavier fish at a given length are in better condition. The condition factor $(K)$ was calculated as:

$$
K=\frac{100 w}{l^{3}}
$$

where $w$ and $l$ are the individual fish weight (g) and total length $(\mathrm{cm})$, respectively.

\section{Estimation of gonado-somatic index (GSI)}

Gonado-somatic index (GSI) is a measure that describes the state of maturity of a fish by expressing the weight of the gonads as a percentage of fish weight. Normally, the value of GSI increases as the development of fish gonads approaches ripeness; the value begins to decrease as the fish starts to spawn. The GSI was calculated using the following formula:

$$
\text { GSI }=\frac{\text { Gonad weight }}{\text { Weight of evicerated fish }} \times 100
$$

Table 2 Description of maturity stages of female O. niloticus as adopted from Mous et al. (1995)

\footnotetext{
Stage l: Immature: Appearance like testes; sexes indistinguishable macroscopically

Stage II: Early developing: Ovaries to be recognized by small whitish dots (eggs); caudal part of the ovaries more thickened than the rostral part

Stage III: Developing or recovering: Eggs developing inside the ovaries unequal in size

Stage IV: Early ripening: Eggs equal in size but not fully grown; all coloured yellow

Stage V: Ripe: Eggs large and ovaries visible from the ventral side of the cavity

Stage VI: Spent: Eggs or juveniles in the buccal cavity; ovaries recovering, thin and reddish; eggs unequal in size, often including a few residual stage $V$ eggs
} 


\section{Determination of fecundity and egg diameter}

Fecundity is estimated from the gonads in the final maturation stage by counting oocytes having the largest diameter (Duponchellé et al. 2000). The absolute fecundity is the total number of ripe eggs prior to the next spawning period. The relative fecundity is the total number of ripe eggs per gram of female body weight (Bagenal 1978). Absolute fecundity was determined by counting the number of eggs in the ripe gonads through a gravimetric subsampling method (Bagenal 1978). The procedure involved weighing of the whole ripe gonads (stage $\mathrm{V}$ ) stored in $4 \%$ formaldehyde. A small portion from each lobe taken from the posterior, middle and anterior regions was weighed and the number and weight of ripe eggs were determined. The total number of ripe eggs in the gonad from a single fish was calculated by using the following formula:

$$
E=\frac{w_{g} e_{s}}{w_{e}}
$$

where $E$ is the total number of eggs in a gonad; $w_{g}$ is weight of the gonad; $e_{s}$ is number of eggs in the sample; and $w_{e}$ is weight of eggs in the egg sample.

The most advanced maturity stage encountered was determined by counting ovaries with GSI larger than 3\% in order to determine the absolute fecundity (de Graaf et al. 1999). The egg size was determined by measuring the diameter of 40-55 randomly selected eggs per female along two axes in the counting chamber under a microscope using a calibrated eyepiece ocular micrometer at $40 \times$ magnification. At the end of the study, a comparison was made in terms of growth and yield performance between monoculture and polyculture systems as done by Shoko et al. (2011).

\section{Statistical analyses}

Data were tested for homogeneity of variances using Levene's test. A two tailed $t$ test was used to compare the estimates of $\mathrm{L}_{50}$, fecundity, condition factor, GSI, growth and yield between monoculture and polyculture systems. Linear regression analysis was used to test the relationship between fecundity and total length; fecundity and total weight and fecundity and oocytes diameter in monoculture and polyculture systems. Linear regression analysis was also used to test the relationship between condition factor and absolute fecundity. Fisher's Z-test was used to compare correlation coefficients (r) between the two culture systems (Zar 2010). All statistical analyses were performed using SPSS 13 for Windows (Landau and Everit 2004). Significance of differences was judged at $\mathrm{p}<0.05$.

\section{Results}

Mature gonads of female O. niloticus reared under monoculture and polyculture systems started to appear at total length of 6-11 cm and $11-16 \mathrm{~cm}$, respectively (Figure 2a, b). In both culture systems, the percentage of mature females increased with the increase in female length.

Overlaps in total lengths among the five maturity stages from both culture systems were observed as indicated by the error bars in Figure 3 based on medians and percentiles for each category. The immature stages were observed in small females in both systems (Figure 3a, b).

Females reared under monoculture and polyculture systems attained the $\mathrm{L}_{50}$ at a total length of 16.38 and $16.59 \mathrm{~cm}$, respectively (Figure $4 \mathrm{a}, \mathrm{b}$ ) with no significant difference $(t=1.96, d f=\infty, p>0.05)$ between the two culture systems.

The absolute fecundity of $O$. niloticus reared in monoculture and polyculture ponds ranged from 678.00 to 2,086.00 and $662.00-2,096.00$ with the corresponding total lengths of $15.50-21.00$ and $15.00-21.20 \mathrm{~cm}$, respectively. The absolute fecundity of females reared in monoculture was strongly correlated with total length $(\mathrm{r}=0.96, \mathrm{df}=33, \mathrm{p}=0.000)$ and total weight $(\mathrm{r}=0.92, \mathrm{df}=33, \mathrm{p}=0.000)$ (Figure $5 \mathrm{a}, \mathrm{b})$ while it was
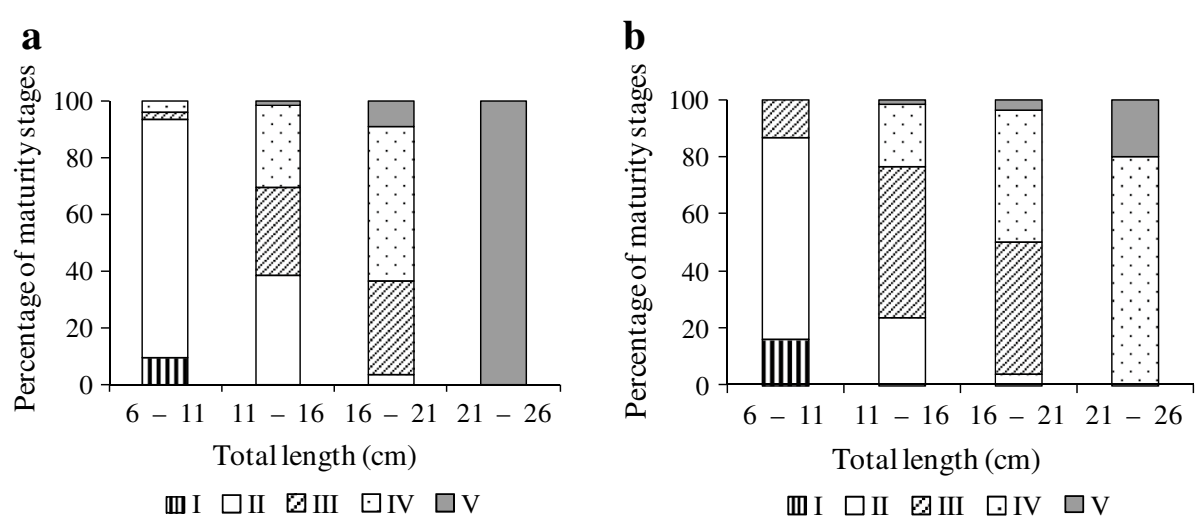

Figure 2 Percentage of each maturity stage for $5 \mathrm{~cm}$ length groups of female 0 . niloticus reared under monoculture (a) and polyculture (b). 

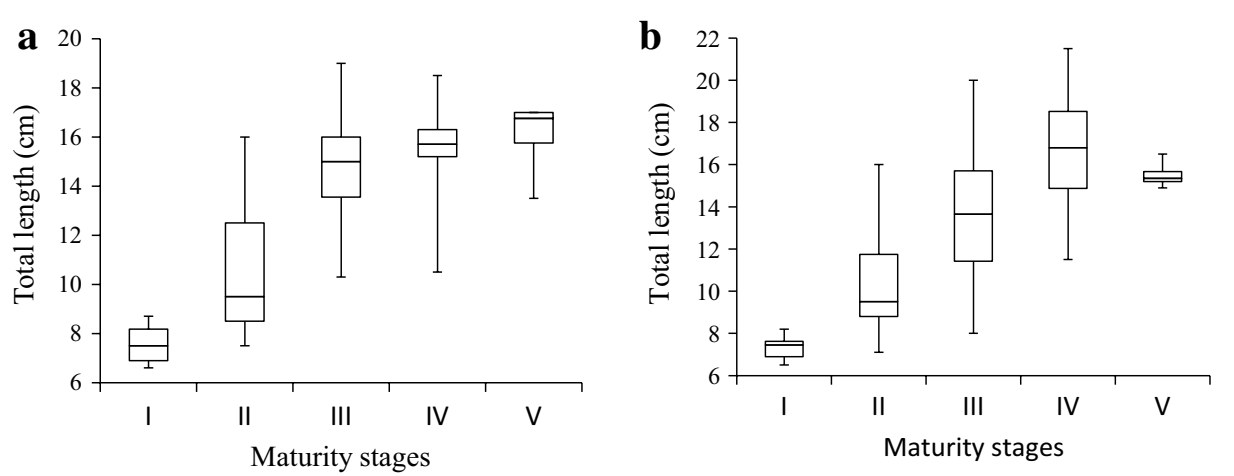

Figure 3 Box-and-whisker plots showing the total lengths ( $\mathrm{cm}$ ) of O. niloticus females within each maturity stage reared under monoculture (a) and polyculture (b) conditions.
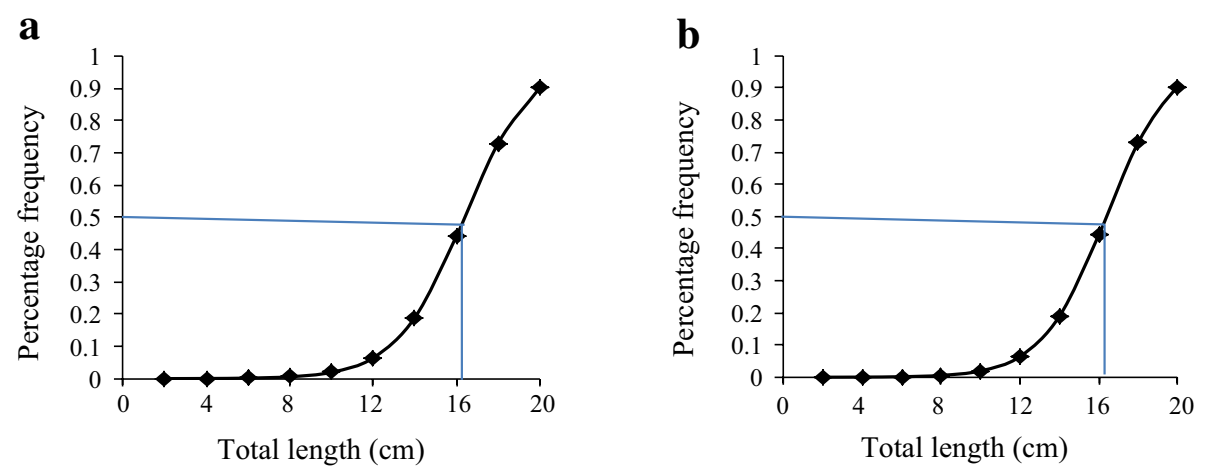

Figure 4 Length at $L_{50}$ sexual maturity of female $O$. niloticus reared under monoculture (a) and polyculture (b) conditions.

weakly correlated with ovary weight $(\mathrm{r}=0.72 \mathrm{df}=33$, $\mathrm{p}=0.000$ ) (Figure 6a). Likewise, absolute fecundity was also strongly correlated with total length $(r=0.91, \mathrm{df} 31$, $\mathrm{p}=0.000)$ and total weight $(\mathrm{r}=0.89, \mathrm{df}=31, \mathrm{p}=0.000)$ (Figure $7 \mathrm{a}, \mathrm{b})$ than with ovary weight $(\mathrm{r}=0.72, \mathrm{df}=31$, $\mathrm{p}=0.000$ ) in polyculture system (Figure $6 \mathrm{~b}$ ). However, there was no significant difference in absolute fecundity between the two systems $(t=1.810, d f=66, p=0.075)$.

Oocyte diameter ranged from 1.36 to $2.04 \mathrm{~mm}$ and $1.32-2.20 \mathrm{~mm}$ in monoculture and polyculture, respectively. No significant correlation existed between absolute fecundity and oocyte diameter in monoculture system $(\mathrm{r}=0.07, \mathrm{df}=33, \mathrm{p}=0.0688)$ (Figure $8 \mathrm{a})$. Similarly, O. niloticus cultured in polyculture system did not show any significant correlation between absolute fecundity and oocyte diameter $(\mathrm{r}=0.13, \mathrm{df}=31, \mathrm{p}=0.452)$ (Figure 8b).

No significant difference was observed in GSI $(\mathrm{t}=-1.012, \mathrm{df}=66, \mathrm{p}=0.315)$ and condition factor $(t=0.172, d f=66, p=0.864)$ between the two culture systems with no relationship between the two parameters. However, a negative relationship between condition factor and relative fecundity under both culture systems was realized.

There were no significant differences in correlation coefficients of fecundity and total length $(\mathrm{z}=1.748$, $\mathrm{p}=0.941)$, total weight $(\mathrm{z}=0.681, \mathrm{p}=0.592)$ and oocytes diameter $(\mathrm{z}=0.263, \mathrm{p}>0.257)$ between monoculture and polyculture systems. O. niloticus reared under monoculture showed significantly lower mean specific growth rates $(t=2.669, \mathrm{df}=178, \mathrm{p}=0.008)$, total weight gain $(\mathrm{t}=-5.277, \mathrm{df}=1,782, \mathrm{p}=0.000)$ and individual final weight $(\mathrm{t}=-5.217, \mathrm{df}=162, \mathrm{p}=0.000)$ than in polyculture (Table 3 ).

\section{Discussion}

The present study was conducted to determine the reproductive biology of female $O$. niloticus reared in monoculture and polyculture pond systems. The results from this study negate the hypothesis that O. niloticus reared in monoculture would attain sexual maturity earlier and at a smaller size than those in polyculture. This indicates that early breeding in $O$. niloticus under captivity is not affected by the type of culture system used. 

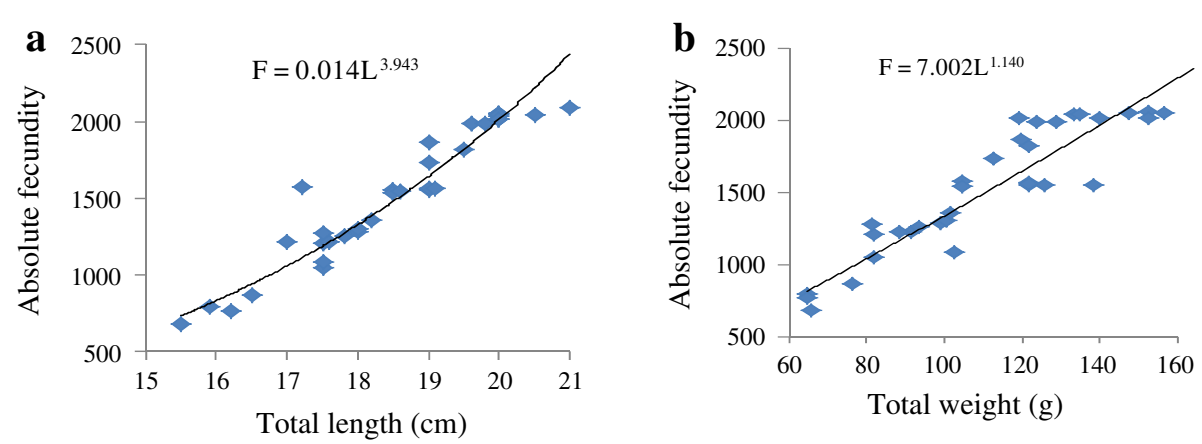

Figure 5 Relationship between absolute fecundity and total length (a), absolute fecundity and total weight (b) reared under monoculture system.
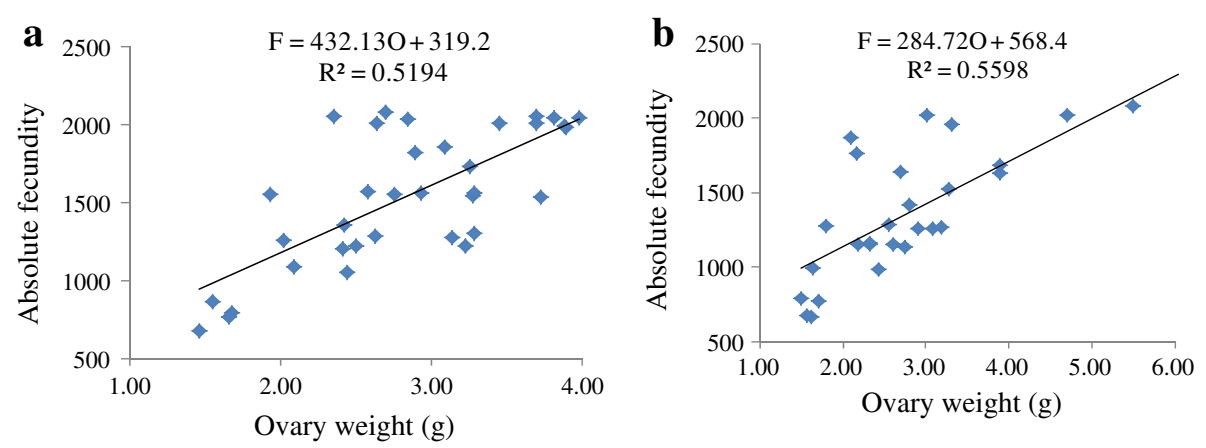

Figure 6 Relationship between absolute fecundity and ovary weight of O. niloticus reared under monoculture (a) and polyculture (b) system.
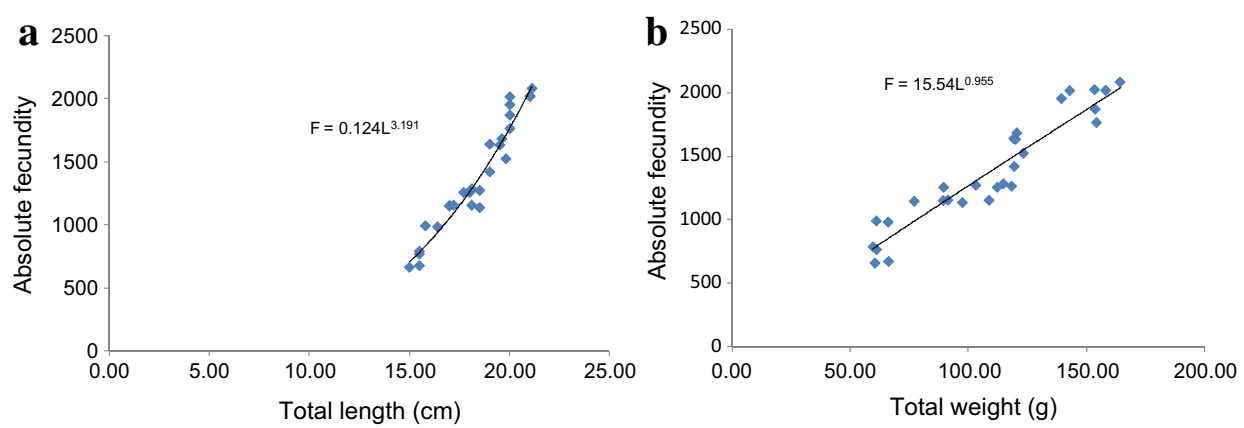

Figure 7 Relationship between absolute fecundity and total length (a), absolute fecundity and total weight (b) reared under polyculture system.

Findings of this study are in agreement with those reported by de Graaf et al. (1999) who suggested that pond environmental conditions are not a major cause for precocious breeding of Nile tilapia. However, LoweMcConnell (1982) stated that early breeding in O. niloticus can be influenced by the low condition factor which is influenced by the quality of food and protein levels (Gunasekera et al. 1995). In the present study, $50.00 \%$ of females reached sexual maturity at body length of 16.38 and $16.59 \mathrm{~cm}$ in monoculture and polyculture, respectively. These values are comparable to those reported by Peña-Mendoza et al. (2005), but higher than those (8.00-13.00 cm TL) reported by de Silva and Radampola (1990) and Siraj et al. (1983). More importantly, it seems that $O$. niloticus used in the present study exhibited neoteny (early breeding). However, neoteny did not reduce somatic growth because specific growth rates in both systems are similar to 1.35 and $1.47 \%$ obtained by 

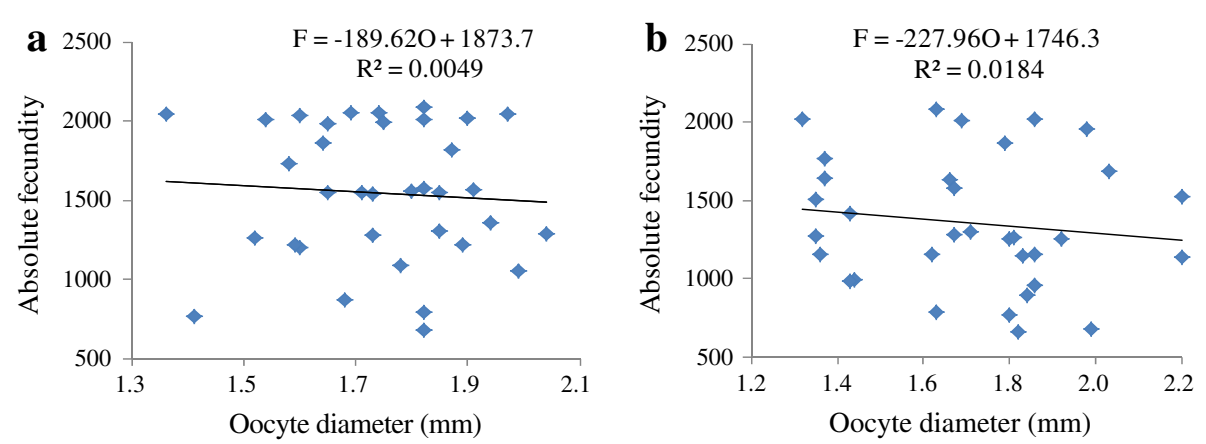

Figure 8 Relationship between absolute fecundity and oocyte length of O. niloticus reared under monoculture (a) and polyculture (b) system.

Table 3 Mean growth rates and yield parameters of O. niloticus cultured under monoculture and polyculture ponds (data are mean \pm SE)

\begin{tabular}{|c|c|c|}
\hline Production parameter & Monoculture & Polyculture \\
\hline Average initial weight (g) & $5.01 \pm 0.05^{\mathrm{a}}$ & $5.01 \pm 0.05^{\mathrm{a}}$ \\
\hline Rearing period (days) & 240 & 240 \\
\hline Average final weight (g) & $123.64 \pm 2.57^{a}$ & $146.58 \pm 3.56^{b}$ \\
\hline Total weight gain & $118.63 \pm 2.58^{\mathrm{a}}$ & $141.57 \pm 3.56^{b}$ \\
\hline Survival rate (\%) & $92.13 \pm 1.70^{\mathrm{a}}$ & $96.62 \pm 3.97^{b}$ \\
\hline Specific growth rates (\%) & $1.33 \pm 0.01^{\mathrm{a}}$ & $1.40 \pm 0.04^{b}$ \\
\hline Gross fish yield (tonha ${ }^{-1}$ ) & $10.27 \pm 0.55^{\mathrm{a}}$ & $15.25 \pm 0.64^{b}$ \\
\hline Net fish yield (tonha ${ }^{-1}$ ) & $10.26 \pm 0.54^{\mathrm{a}}$ & $15.25 \pm 0.64^{b}$ \\
\hline Net annual yield (tonha ${ }^{-1} \mathrm{yr}^{-1}$ ) & $1797.25 \pm 95.44^{\mathrm{a}}$ & $2671.30 \pm 111.55^{b}$ \\
\hline
\end{tabular}

Values with dissimilar superscripts in a row are significantly different ( $t$ test).

Abdel-Hakim et al. (2008) from monosex rearing of Nile tilapia. Specific growth rates of 1.33 and $1.40 \%$ were obtained from monoculture and polyculture systems respectively in this study.

The present study showed overlaps in the ranges of total length among the different maturity stages. This is attributed to the fact that, maturation in O. niloticus does not depend only on length but it is also controlled by other factors such as food availability and water quality (Babiker and Ibrahimu 1979; Southgate and Lucas 2012). Changes in these factors are translated as neural signals which stimulate the pituitary gland and gonads to respond to the above triggers (Southgate and Lucas 2012).

The insignificant difference in GSI between monoculture $(3.86 \%)$ and polyculture $(4.33 \%)$ indicates that culture system has no effect on GSI. The GSI values from the present study are comparable with the maximum GSI of $3.60,4.00,4.70$ and $4.80 \%$ reported by Babiker and Ibrahimu (1979), Hirpo (2012), Ambali and Little (1996) and Behrends and Smitherman (1983), respectively but lower than the $7.00 \%$ reported by de Graaf et al. (1999). The difference in experimental conditions could have contributed to the differences in maximum GSI obtained from the present study.

The insignificant difference obtained in the absolute fecundity of $O$. niloticus raised in monoculture and polyculture systems further support the notion that culture system has no effect on the reproductive capacity of the females. In the present study, the absolute fecundity ranges of $678.00-2,086.00$ and $662.00-2,096.00$ recorded in monoculture and polyculture, respectively are higher than the ranges of 289.00-1,456.00 and 104.00-709.00 for O. niloticus with $10.00-23.00 \mathrm{~cm}$ and $12.50-20.90 \mathrm{~cm}$ reported by Shalloof and Salama (2008) and Gómez-Márquez et al. (2003) respectively. Furthermore, the fecundity reported in the present study is lower than the maximum absolute fecundity of 2,603.00 with a corresponding total length of $34.90 \mathrm{~cm}$ reported by Peterson et al. (2004). Variation in fecundity could be attributed to the differences in experimental conditions.

In the present study absolute fecundity of $O$. niloticus reared under both monoculture and polyculture was strongly correlated with weight and total length than with ovary weight. These results are consistent with the results obtained by Gómez-Márquez et al. (2003), Murua et al. (2003), Peterson et al. (2004) and Shalloof and Salama (2008) who found that fecundity was directly correlated with body total length and weight. No correlation existed between absolute fecundity and oocyte diameter in O. niloticus cultured under either system. This is because in fishes, the size of ripe eggs does not vary much with the size or age of the fish. This finding is in agreement with that of Shalloof and Salama (2008). The size of oocytes reported from the present study ranged from 1.36 to $2.04 \mathrm{~mm}$ and $1.32-2.20 \mathrm{~mm}$ in O. niloticus reared under monoculture and polyculture ponds, respectively. These oocyte sizes are comparable with the size of 1.00$3.00 \mathrm{~mm}$ reported by Gómez-Márquez et al. (2003) and $1.80-2.45 \mathrm{~mm}$ reported by Babiker and Ibrahimu (1979), 
Siraj et al. (1983), Smitherman et al. (1988), de Graaf et al. (1999) and Shalloof and Salama (2008).

The significantly higher growth and yield of $O$. niloticus reared in polyculture than the monoculture system can be attributed to the reduced number of O. niloticus fingerlings as a result of predation by C. gariepinus and to the less competition for food and space. This improved growth performance in polyculture is in agreement with the findings reported by de Graaf et al. (1996), El Gamal et al. (1998), Liti et al. (2002) and Offem et al. (2009).

This study showed that, female size at first maturity in $O$. niloticus is not affected by the culture systems used. Moreover, adding C. gariepinus to Nile tilapia population reduced the number of unwanted tilapia fingerlings and improved growth performance and yield. However, further studies are necessary to determine the size of $C$. gariepinus for maximum elimination of the unwanted tilapia population for maximum tilapia growth and yield.

\section{Authors' contribution}

Conceived, designed the experiments, collected and analysed data and drafted the manuscript: APS, SML and HDJM. Designed and supervised the study including data analysis: YDM. All authors read and approved the final manuscript.

\section{Author details}

${ }^{1}$ Tanzania Fisheries Research Institute, Institute Headquarters, P. O. Box 9750, Dar es Salaam, Tanzania. ${ }^{2}$ Department of Aquatic Sciences and Fisheries, University of Dar es Salaam, P. O. Box 35064, Dar es Salaam, Tanzania. ${ }^{3}$ Tanzania Fisheries Research Institute, Mwanza Centre, P. O. Box 475, Mwanza, Tanzania.

\section{Acknowledgements}

This work was supported by the Inter-University Council for East Africa through Lake Victoria Research (VicRes) Initiative project and the Government of Tanzania through Commission for Science and Technology. Tanzania Fisheries Research Institute and the University of Dar es Salaam are acknowledged for granting the authors permission to participate in the study. We are also grateful to the cooperation provided by the local fish farmers in the study area.

\section{Compliance with ethical guidelines}

\section{Competing interests}

The authors declare that they have no competing interests.

Received: 31 October 2014 Accepted: 12 May 2015

Published online: 17 June 2015

\section{References}

Abdel-Hakim NF, Ammar AA, Salah A-EA (2008) Effect of initial stocking size and production cycle on growth performance of mono sex tilapia reared in earthen ponds. Presented at the 8th international symposium on tilapia in aquaculture. The Central Laboratory for Aquaculture Research, Cairo, Egypt, pp 255-268

Abdel-Tawwab M (2005) Predation efficiency of African sharp-tooth catfish, Clarias gariepinus on fry Nile tilapia, Oreochromis niloticus: effect of prey density, predator size, feed supplementation and submerged vegetation. Turk J Fish Aquat Sci 5:69-74

Ambali AJD, Little DC (1996) Studies on the effect of manipulating hapa size on broodstock conditioning of Oreochromis niloticus in fertilized earthen ponds. In: Pullin RSV, Lazard J, Legendre M, Kothias AJB, Pauly D (eds) The 3rd international symposium on tilapia in aquaculture ICLARM conference proceedings No 14, Manila, Philippines, pp 223-228

Babiker MM, Ibrahimu H (1979) Studies on the biology of reproduction in the cichlid Tilapia nilotica (L.): gonadal maturation and fecundity. J Fish Biol 14:437-448

Bagenal TB (1978) Methods for assessment of fish production in freshwaters. Blackwell Scientific Publications, Oxford, p 365

Bardach JE, Ryther JH, McLarney WO (1972) Aquaculture: the farming and husbandry of fresh water and marine organisms. Wiley-Interscience Inc, New York, p 868

Behrends LL, Smitherman RO (1983) Use of warm water effluents to induce winter spawning of Tilapia in temperate climate. In: Fishelson L, Yaron Z (eds) Proceedings of the 1st international symposium on tilapia in aquaculture, Tel Aviv, Israel, pp 446-454

de Graaf G, Galemoni F, Banzoussi B (1996) Recruitment control of Nile tilapia, Oreochromis niloticus by the African catfish, Clarias gariepinus (Burchell, 1822), and the African Snakehead, Ophicephulus obscures. I. a biological analysis. Aquaculture 146(1-2):85-100

de Graaf GJ, Galemoni F, Huisman EA (1999) The reproductive biology of pond reared Nile tilapia (Oreochromis niloticus niloticus L.). Aquacult Res 30:25-33

de Silva SS, Radampola K (1990) Effect of dietary protein level on the reproductive performance of Oreochromis niloticus. In: Hirano R, Hanyu I (eds) The Second Asian Fisheries Forum Asian Fisheries Society, Manila, Philippines, pp 559-563

Duponchellé F, Cecchi PH, Corbin D, Nuñeï J, Legendré M (2000) Variations in fecundity and egg size of female Nile tilapia, Oreochromis niloticus, from man-made lakes of Côte d'ivoire. Environ Biol Fishes 57:155-170

El Gamal AA, Abdel-Halim AMM, Abdel-Razek E, Solomon A (1998) Biological studies on the Nile perch Lates niloticus $(\mathrm{L})$ and African catfish Clarias gariepinus (T.) in reference to their food habits and predation pattern in culture ponds. Egypt J Agric Res 76:335-349

Engle CR, Neira I (2005) Tilapia farm business management and economics: a training manual. Aquaculture CRSP, Oregon State University, Corvallis, p 41

Fryer FE, lles TD (1972) The cichlid fishes of the great lakes of Africa: their biology and evolution. Oliver and Boyd Publications, Edinburgh, p 641

Gómez-Márquez JL, Peña-Mendoza B, Salgado-Ugarte IH, Guzmán-Arroyo M (2003) Reproductive aspects of Oreochromis niloticus (Perciformes: Cichlidae) at Coatetelco lake, Morelos, Mexico. Rev Biol Trop 51(1):221-228

Grigorakis K (2010) Ethical issues in aquaculture production. J Agricult Environ Ethics 23(4):345-370

Guerrero RD (1982) Control of tilapia reproduction. In: Pullin RSV, McConnell RHL (eds) The biology and culture of tilapias ICLARM conference proceedings No 7, Manila, Philippines, pp 309-316

Gunasekera RM, Shim KF, Lam TJ (1995) Effect of dietary protein level on puberty, oocyte growth and egg chemical composition in the tilapia, Oreochromis niloticus (L.). Aquaculture 134:169-183

Gwahaba JJ (1973) Effects of fishing on Tilapia nilotica (L.) population in L. George, Uganda, over the past twenty years. E Afr Wildl J 11:317-328

Håstein T (2004) Animal welfare issues relating to aquaculture. In: Vallat B (ed) Global conference on animal welfare: an OIE initiative. European Communities, Paris, France, pp 212-221

Hirpo LA (2012) Breeding season and condition factor of Oreochromis niloticus (Pisces: Cichlidae) in Lake Babogaya, Ethiopia. Int J Agric Sci 2(3):116-120

Jegede T (2010) Control of reproduction in Oreochromis niloticus (Linnaeus 1758) using Hibiscus rosa-sinensis (Linn.) leaf meal as reproduction inhibitor. J Agric Sci 2(4):149-154

King RP, Udo MT (1998) Dynamics in the length-weight parameters of the mudskipper, Periophthalmus barbarus (Gobiidae), in Imo River estuary, Nigeria. Helgol Meeresunters 52:179-186

Landau S, Everit BS (2004) A handbook of statistical analyses using SPSS. Chapman and Hall/CRC Press LLC, London, p 339

Liti DM, Mac'Were OE, Veverica KL (2002) Growth performance and economic benefits of Oreochromis niloticus/Clarias gariepinus polyculture fed on three supplementary feeds in fertilized tropical ponds. In: McElwee K, Lewis K, Nidiffer M, Buitrago P (eds) 19th annual technical report pond dynamics/Aquaculture CRSP, Oregon State University, Corvallis, Oregon, pp 11-16

Lowe-McConnell RH (1958) Observations on the biology of Tilapia nilotica (L.) in East African waters. Rev Zool Bot Afric 57:129-170 
Lowe-McConnell RH (1982) Tilapia in fish communities. In: Pullin RSV, LoweMcConnel RH (eds) The biology and culture of tilapia ICLARM conference proceedings No 7, Manila, Philippines, pp 83-113

Mair GC, Little DC (1991) Population control in farmed tilapias. NAGA Int Cent Living Aquat Resour Manag (ICLARM) Q 4:8-9

Marriot MS, Booth AJ, Skeleton PH (1997) Reproductive and feeding biology of the Natal mountain catfish Amphilius natalensis (Siluriformes: Amphiliidae). Environ Biol Fishes 46:461-470

McGinty AS (1985) Effects of predation by largemouth bass in fish production ponds stocked with Tilapia nilotica. Aquaculture 46:269-274

Moreau J, Bambino C, Pauly D (1986) Indices of overall performance of 100 tilapia (Cichlidae) population. In: Maclean JL, Dizon LB, Hosillos LV (eds), The First Asian Fisheries Forum, Manila. Asian Fisheries Society, Manila, Philippines, pp 201-221

Mous PJ, Goudswaard PC, Katunzi EFB, Budeba YL, Witte F, Ligtvoet W (1995) Sampling and measuring. In: Witte F, van Densen WLT (eds) Fish stocks and fisheries of Lake Victoria: a handbook for field observations. Samara Publishing House Limited, Samara House, Cardigan, Dyfed SA43 2JG., Great Britain, pp 55-82

Murua H, Kraus G, Saborido-Rey F, Witthames PR, Thorsen A, Junquera S (2003) Procedures to estimate fecundity of marine fish species in relation to their reproductive strategy. J Northwest Atl Fish Sci 33:33-54

Offem BO, Ikpi GU, Ayotunde EO (2009) Effect of stocking size of the predatory African catfish (Heterobranchus longifilis V.) on the growth performance of Nile tilapia (Oreochromis niloticus L.) in pond culture. Int J Fish Aquacult $1: 38-43$

Peña-Mendoza B, Gómez-Márquez J, Salgado-Ugarte I, Ramírez-Noguera D (2005) Reproductive biology of Oreochromis niloticus (Perciformes: Cichlidae) at Emiliano Zapata dam, Morelos, Mexico. Rev Biol Trop 53(3-4):515-522

Peterson MS, SlackWT, Brown-Peterson NJ, Mcdonald JL (2004) Reproduction in non-native environments: establishment of Nile tilapia, Oreochromis niloticus, in coastal Mississippi watersheds. Copeia 4:842-849

Shalloof KAS, Salama HMM (2008) Investigations on some aspects of reproductive biology in Oreochromis niloticus (Linnaeus, 1757) inhabited Abu-zabal Lake, Egypt. Global Vet 2(6):351-359

Shoko AP, Getabu A, Mwayuli G, Mgaya YD (2011) Growth performance, yields and economic benefits of Nile tilapia Oreochromis niloticus and Kale Brassica oleracea cultured under vegetable-fish culture integration. Tanz J Sci 37:37-48
Shoko AP, Limbu SM, Mrosso HDJ, Mgaya YD (2014a) A comparison of diurnal dynamics of water quality parameters in Nile tilapia (Oreochromis niloticus, Linnaeus, 1758) monoculture and polyculture with African sharp tooth catfish (Clarias gariepinus, Burchell, 1822) in earthen ponds. Int Aquat Res 6(56):1-13

Shoko AP, Limbu SM, Mrosso HDJ, Mkenda AF, Mgaya YD (2014b) Effect of stocking density on growth, production and economic benefits of mixed sex Nile tilapia (Oreochromis niloticus) and African sharptooth catfish (Clarias gariepinus) in polyculture and monoculture. Aquacult Res. doi:10.1111/are.12463

Silberberg KR, Laidig TE, Adams PB (2001) Analysis of maturity in lingcod, Ophiodon elongatus. Calif Fish Game 87(4):139-152

Siraj SS, Smitherman RO, Castillo-Galuser S, Dunham RA (1983) Reproductive traits for three year classes of Tilapia nilotica and maternal effects on their progeny. In: Fishelson L, Yaron Z (eds) Proceedings of international symposium on aquaculture. Tel Aviv University, Israel, Nazaret, Israel, pp $210-218$

Smitherman RO, Khater AA, Cassel NI, Dunham RA (1988) Reproductive performance of three strains of Oreochromis niloticus. Aquaculture 70(1-2):29-37

Sneddon L (2006) Ethics and welfare: pain perception in fish. Bull Eur Assoc Fish Pathol 26(1):6-10

Sneddon LU (2012) Clinical anesthesia and analgesia in fish. J Exot Pet Med 21(1):32-43

Southgate P, Lucas J (2012) Reproduction, life cycles and growth. In: Lucas JS, Southgate PC (eds) Aquaculture: farming aquatic animals and plants. Wiley-Blackwell Publishing Ltd, Oxford, pp 126-137

Suresh V, Bhujel RC (2012) Tilapias. In: Lucas JS, Southgate PC (eds) Aquaculture: farming aquatic animals and plants. Wiley-Blackwell Publishing Company, United Kingdom, pp 338-364

URT (1998) United Republic of Tanzania. Mara region socio-economic profile: the planning commission Dar es Salaam and regional commissioner's office Mara, p 224

Yi Y, Lin CK, Diana JS (1996) Influence of Nile tilapia (Oreochromis niloticus) stocking density on their growth and yield in cages and ponds containing the cages. Aquaculture 146:205-215

Zar JH (2010) Biostatistical analysis. Prentice Hall Inc, New Jersey, p 947

\section{Submit your manuscript to a SpringerOpen ${ }^{\circ}$ journal and benefit from:}

- Convenient online submission

- Rigorous peer review

- Immediate publication on acceptance

- Open access: articles freely available online

- High visibility within the field

- Retaining the copyright to your article

Submit your next manuscript at $>$ springeropen.com 